\title{
High-level regulated expression of the human G6PD gene in transgenic mice
}

(mRNA levels; tissue specific; copy-number dependent; glucose-6-phosphate dehydrogenase; housekeeping; Northern blot)

\author{
Colm M. Corcoran ${ }^{\mathrm{a}}$, Peter Fraser ${ }^{\mathrm{b}}$, Giuseppe Martinic ${ }^{\mathrm{c}}$, Lucio Luzzatto ${ }^{\mathrm{a}, *}$ and Philip J. Mason ${ }^{\mathrm{a}}$ \\ a Department of Haematology, Hammersmith Hospital, London W12 0NN, England, UK; ' Department of Cell Biology, Erasmus University, Rotterdam, \\ The Netherlands; and ${ }^{\mathrm{C}}$ Istituto Internazionale di Genetica e Biofisica, CNR, Napoli, Italy
}

Received R.W. Davies: 7 September 1995; Revised/Accepted: 25 November 1995; Received at publishers: 26 January 1996

\section{SUMMARY}

The glucose-6-phosphate dehydrogenase-encoding gene (G6PD) belongs to a group with constitutive expression in all tissues. The regulation of these housekeeping genes is poorly understood, as compared to what is known about many genes whose expression is restricted to a particular tissue or stage of development, and which are often regulated by locus control regions (LCR) able to act over wide distances. In order to identify sequences in human G6PD which are necessary for its expression, we have generated transgenic mice carrying a $20-\mathrm{kb} G 6 P D$ construct, including only $2.5 \mathrm{~kb}$ of upstream and $2.0 \mathrm{~kb}$ of downstream flanking sequence. All mice which carried the transgene (TG) expressed it, and the levels of expression detected in a range of tissues from three independent lines of mice were comparable to that of the endogenous murine G6PD. The variation in enzyme activity from tissue to tissue was remarkably similar for both the TG and the endogenous gene, and was shown to be due in both cases to variations in the steady-state mRNA levels.

\section{INTRODUCTION}

The X-linked human G6PD gene is a typical housekeeping gene, point mutations in which cause red cell G6PD deficiency, a common human enzymopathy associated with protection against malaria (Vulliamy et al., 1992; Ruwende et al., 1995). Although ubiquitous, the expression of $G 6 P D$ is not uniform; basal activity varies from one tissue to another and is also regulated within individual tissues (reviewed in Kletzien et al., 1994)

Correspondence to: Dr. P.J. Mason, Department of Haematology, Royal Postgraduate Medical School, Hammersmith Hospital, Ducane Road, London W12 0NN, UK. Tel. (44-181) 740-3235; Fax (44-181) 742-9335; e-mail: pmason@mpcc3.rpms.ac.uk

* Present address: Department of Human Genetics, Memorial SloanKettering Cancer Center, 1275 York Avenue, New York, NY 10021, USA. Tel. (1-212) 639-6165

Abbreviations: bp, base pair(s); cDNA, DNA complementary to DNA;
Several elements necessary for the basic expression of the $\mathrm{X}$-linked human G6PD gene are known. Functional analysis of the GC-rich, $5^{\prime}$ region has revealed that the proximal $140 \mathrm{bp}$ upstream from the transcription start point $(t s p)$ constitutes the minimal promoter (Ursini et al., 1990; Philippe et al., 1994).

Very little is known of the molecular mechanisms regulating the levels of G6PD expression in different tissues. The analysis of tissue restricted genes has pointed out transcription as the step at which most regulation occurs

G6PD, glucose-6-phosphate dehydrogenase; $G 6 P D$, gene encoding G6PD; GAPDH, glyceraldehyde-3-phosphate dehydrogenase; GAPDH, gene encoding GAPDH; kb, kilobase(s) or $1000 \mathrm{bp}$; IU, international unit(s) (of G6PD activity); LCR, locus control region(s); NADP and NADPH, nicotinamide-adenine dinucleotide phosphate and its reduced form; NTG, non-transgenic; nt, nucleotide(s); PCR, polymerase chain reaction; Sp 1, stimulatory protein 1; SSC, $0.15 \mathrm{M} \mathrm{NaCl} / 0.015 \mathrm{M}$ $\mathrm{Na}_{3}$-citrate $\mathrm{pH}$ 7.6; TG, transgenic or transgene(s); tsp, transcription start point. 
and has revealed the importance of LCRs, cis-acting elements able to regulate homologous transcriptional units distributed in ranges up to $100 \mathrm{~kb}$ (reviewed in Dillon and Grosveld, 1993). Such an LCR is located a few hundred $\mathrm{kb}$ downstream from G6PD and controls the retina-specific expression of the red/green color vision gene cluster (Wang et al., 1992). More importantly, G6PD is part of a highly gene-dense region characterized by CpG islands associated with ubiquitously expressed genes (Bione et al., 1993). Therefore, as a first step towards understanding the tissue-specific regulation of the G6PD gene we aimed to delimit the region containing cis-active elements and, to this end, we have produced TG mice containing the complete human G6PD gene, including $2.5 \mathrm{~kb}$ of $5^{\prime}$ and $2 \mathrm{~kb}$ of $3^{\prime}$ flanking sequence.

\section{EXPERIMENTAL AND DISCUSSION}

\section{(a) Production of TG (transgenic) lines}

Transgenic (TG) mouse lines were generated using a 20-kb human genomic DNA construct containing the $G 6 P D$ gene. The construct, designated Gd15 contains the entire $G 6 P D$ gene including $2.5 \mathrm{~kb}$ of upstream flanking sequence and $2.0 \mathrm{~kb}$ of downstream flanking sequence (Fig. 1). After removal of vector sequences the DNA was injected into the male or female pronuclei of oocytes freshly prepared from CB3 mice. Two sessions of injection yielded a total of 81 progeny of which nine were shown to carry the human G6PD gene by DNA amplification of tail biopsy DNA using specific primers. The presence of the TG in the PCR-positive mice was confirmed by Southern blotting. One founder mouse died and the

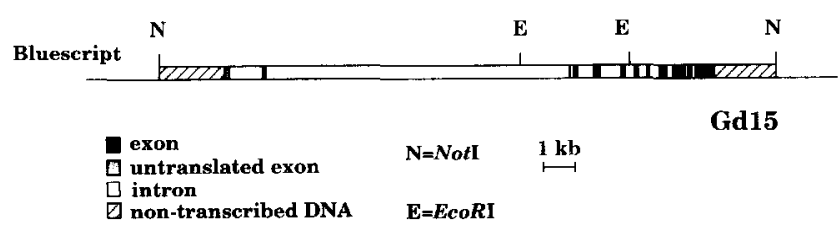

Fig. 1. Human G6PD construct used for microinjection. The TG used (Gd15) spanned $20105 \mathrm{bp}$ of the human G6PD locus. In the cloned construct, the flanking $E c o$ RI sites have been converted to NotI sites. Methods: A pBluescript (Stratagene, La Jolla, CA, USA) sub-clone containing the $5^{\prime} 11.7-\mathrm{kb} E c o$ RI genomic G6PD fragment was cut with $E c o \mathrm{RV}$ in the vector just upstream from the $5^{\prime} \mathrm{G} 6 \mathrm{PD} E c o \mathrm{RI}$ site, trimmed with BAL31, ligated to NotI linkers and cut with EcoRI + NotI to generate an EcoRI-NotI insert; another sub-clone containing the $3^{\prime}$ 4.9-kb genomic G6PD EcoRI fragment was cut with HindIII in the vector just downstream from the $3^{\prime} G 6 P D E c o$ RI site, filled in, ligated with NotI linkers and cut with $E c o$ RI + NotI to generate another $E c o$ RINotI insert; a sub-clone containing a $3.5-\mathrm{kb} E c o \mathrm{RI}$ fragment from the middle portion of the G6PD gene was isolated from $\mu \mathrm{UC18}$ by EcoRI restriction. The three inserts thus generated were ligated together into a NotI-cut, phosphatase-treated pBluescript vector to generate Gd15. For microinjection, the TG was isolated from the vector by NotI digestion. remaining eight were mated with NTG (non-transgenic) mice to establish TG lines; three of the founders were capable of transmitting the TG to their offspring and three lines, designated PF5, PF8 and PF17 were established. DNA samples from the tails of mice from each of the lines were subjected to restriction analysis by Southern blotting using radioactively-labelled probes from human G6PD genomic DNA or cDNA (DNA complementary to RNA). The pattern of labelled bands, and their relative intensities measured by phophorimaging, were used to deduce the arrangement and copy number of the TG in each mouse line. In all lines TG were arranged in tandem, head to tail orientation. PF5 had three and PF17 had five complete copies. PF8 had two complete copies and a third incomplete copy with $5 \mathrm{~kb}$ deleted from its $5^{\prime}$ end (data not shown).

\section{(b) TG expression in the peripheral blood of potential founder mice}

We used the fact that G6PD is expressed in adult blood cells to rapidly assay all potential founder mice for TG expression. Samples of peripheral blood $(50 \mu 1)$ were taken from mice carrying the TG, and cell lysates were prepared to assay G6PD activity. Lysate activities were measured spectrophotometrically and aliquots containing 0.012 units of G6PD were run on cellulose acetate gels. After sufficient separation of the molecules, the gels were stained for G6PD activity; in each case, they show the mouse enzyme as a fast-running band, the human enzyme made by the TG as a slow-running band and a mousc/human hybrid protcin with intermediate mobility (Fig. 2). All mice previously shown by PCR and Southern analysis to be carrying the TG also expressed it, and the level of enzyme activity attributable to the TG was always similar to the endogenous mouse G6PD activity. It is interesting to note that in the founder mice the mouse and human G6PD homodimer bands are often stronger than the heterodimer, implying that levels of mouse and human G6PD vary between individual cells (those making predominantly one type accounting for the homodimers), i.e., that the founder mice are mosaics. This phenomenon is less pronounced in the founders from which TG lines were obtained, PF5, PF8 and PF17. This level of mosaicism and failure to transmit the TG is rather higher than that found in most TG mouse experiments.

(c) Mouse and human G6PD activity in TG mouse tissues

Lysates were prepared from the lissues of $\mathrm{TG}$ and NTG mice and G6PD activity was measured by following the production of NADPH on a spectrophotometer at $340 \mathrm{~nm}$. In NTG mice, any measured activity was due to the endogenous murine enzyme. In mice from the TG lines the activity measured was the sum of the 


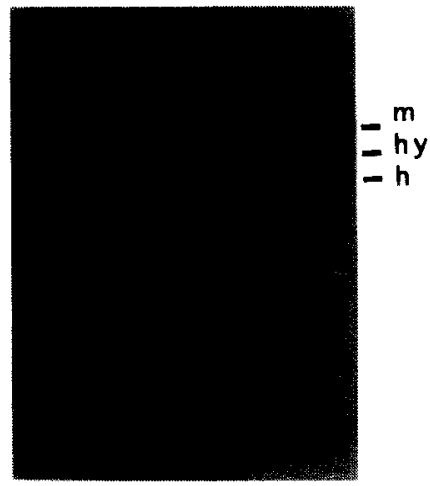

Hu JL23 NTG JL32

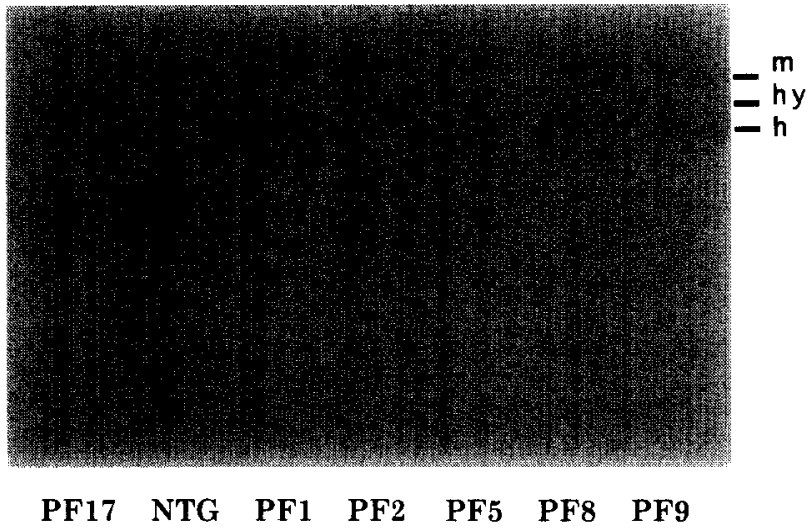

PF17 NTG PF1 PF2 PF5 PF8 PF9

Fig. 2. Cellogel analysis of G6PD activity in peripheral blood samples of potential founder mice carrying the G6PD TG. Lysates were prepared from $50 \mu \mathrm{l} \mathrm{samples} \mathrm{of} \mathrm{peripheral} \mathrm{blood} \mathrm{taken} \mathrm{from} \mathrm{mice} \mathrm{carrying} \mathrm{the} \mathrm{human} \mathrm{G6PD} \mathrm{gene} \mathrm{as} \mathrm{a} \mathrm{result} \mathrm{of} \mathrm{pronuclear} \mathrm{micro-injection,} \mathrm{and} \mathrm{from} \mathrm{human} \mathrm{(Hu)}$ and non-transgenic mouse (NTG) controls. The lysates were analysed on cellogels and stained for G6PD activity. The band running more slowly than the G6PD enzymes is haemoglobin. Methods: The method for the electrophoresis of lysates was a modification of that described previously (Rattazzi et al., 1967). Cellogel strips (Whatman) were equilibrated by gentle shaking for $15 \mathrm{~min}$ at room temperature in $100 \mathrm{ml}$ of buffer ( $84 \mathrm{mM}$ Tris $\mathrm{HCl}$ pH $8.6 / 52 \mathrm{mM}$ boric acid/1.8 mM EDTA) containing $20 \mu \mathrm{M}$ NADP. The cellogel strips were placed in an electrophoresis tank containing the same buffer as above and lysates $(1-10 \mu \mathrm{l})$ were applied using a yellow pipetman tip. Electrophoresis was carried out at $4 \mathrm{C}$ for $75 \mathrm{~min}$ at 130 V. After electrophoresis, the gels were removed from the tank and placed face down in a G6PD-specific staining buffer $(0.1 \mathrm{M} \mathrm{Tris} \cdot \mathrm{HCl} \mathrm{pH} 8.0 / 2 \mathrm{mM}$ $\mathrm{MgCl}_{2} / 0.1 \mathrm{mg} / \mathrm{ml} \mathrm{NADP} / 0.2 \mathrm{mg}$ glucose-6-phosphate $/ 0.1 \mathrm{mg}$ phenazine methosulfate $/ 0.15 \mathrm{mg}$ nitroblue tetrazolium; all per $\left.\mathrm{ml}\right) . \mathrm{m}, \mathrm{hy}$ and $\mathrm{h}$ indicate the positions of the mouse G6PD homodimer the mouse/human (hy = hybrid) heterodimer and the human homodimer, respectively.

activities of the enzymes encoded by the endogenous gene and the introduced genes. The results (Table I) show a clear increase in G6PD activity in all the tissues of the TG mice; the increase is consistently greater for line PF17 which contains 5 copies than in either of the other two lines which have a lower copy number.

In addition, the active enzyme was visualized after electrophoresis on cellulose acetate gels and subsequent staining. In these experiments a constant amount $(0.012$

TABLE I

G6PD specific activity in tissue lysates from NTG and TG mice

\begin{tabular}{|c|c|c|c|c|}
\hline \multirow[t]{3}{*}{ Tissue $^{a}$} & \multicolumn{4}{|l|}{ Mouse line } \\
\hline & NTG & PF5 & PF8 & PF17 \\
\hline & \multicolumn{4}{|c|}{ G6PD activity (IU/g protein $)^{b}$} \\
\hline Liver & $10.0 \pm 1.3$ & $26.0 \pm 0.0$ & $18.6 \pm 3.8$ & $57.2 \pm 21.8$ \\
\hline Lung & $41.0 \pm 0.1$ & $144.1 \pm 31.1$ & $139.3 \pm 40.1$ & $247.9 \pm 138.4$ \\
\hline Brain & $55.4 \pm 20.9$ & $172.0 \pm 20.3$ & $162.2 \pm 62.8$ & $319.3 \pm 41.1$ \\
\hline Colon & $64.8 \pm 26.5$ & $106.3 \pm 3.5$ & $102.4 \pm 24.0$ & $200.5 \pm 105.0$ \\
\hline Heart & $10.6 \pm 2.4$ & $35.8 \pm 8.4$ & $22.1 \pm 6.8$ & $70.3 \pm 37.3$ \\
\hline Kidney & $48.4 \pm 8.9$ & $167.3 \pm 100.8$ & $124.3 \pm 35.1$ & $308.3 \pm 74.3$ \\
\hline Skel. muscle & $8.5 \pm 1.3$ & $15.9 \pm 8.1$ & $25.8 \pm 9.4$ & $49.1 \pm 25.5$ \\
\hline Uterus & $116.0 \pm 23.0$ & $202.6 \pm 54.3$ & $292.9 \pm 200.4$ & $715.1 \pm 436.4$ \\
\hline Spleen & $82.8 \pm 24.6$ & $151.9 \pm 36.5$ & $138.1 \pm 55.1$ & $460.6 \pm 285.2$ \\
\hline Ovary & $165.0 \pm 65.7$ & $340.1 \pm 0.0^{*}$ & $328.6 \pm 3.0$ & $229.7 \pm 0.0^{*}$ \\
\hline
\end{tabular}

a The preparation of lysates from frozen mouse tissues was as described in the legend to Fig. 3.

${ }^{\mathrm{b}}$ Values are means \pm standard deviation; $n=3$ mice in each group, except $*=1$ mouse only.

$\mathrm{IU}=$ International units of enzyme activity.

G6PD activity was assayed as described previously (Calabro et al., 1993). laboratory units) of G6PD activity was loaded in each lane so the relative amounts of staining of the human and murine bands reflect the contribution of each to the total enzyme activity in the tissue. In the different lines and in the different tissues (Fig. 3), the human enzyme was expressed at levels at least as high as the endogenous mouse enzyme. Within each line, the ratio of human to murinc G6PD was similar in the different tissues, suggesting that tissue-specific variations in the regulation of the murine gene were mirrored in the human gene. There was one exception - in the colon, the human enzyme was consistently expressed at relatively lower levels with respect to the endogenous enzyme. The increased activity of human G6PD in line PF17 over lines PF5 and PF8, suggested by the measurement of total activity is clearly observed in the cellogel analysis as an increase in the proportion of enzyme activity in the human over the murine dimer.

\section{(d) Mouse and human G6PD mRNA levels in TG mouse tissues}

The steady-state mRNA levels in TG mouse tissues were examined by Northern blotting. It was possible to compare the levels of mRNA from the endogenous mouse $G 6 P D$ gene with those from the human G6PD transgene by using species specific probes; these were fragments from the $3^{\prime}$ non-coding regions of the genes and were $270 \mathrm{bp}$ and $160 \mathrm{bp}$ long from the human and the mouse genes, respectively.

In the three lines PF8, PF17 and PF5 the mRNA from a range of tissues from different mice was analysed. 


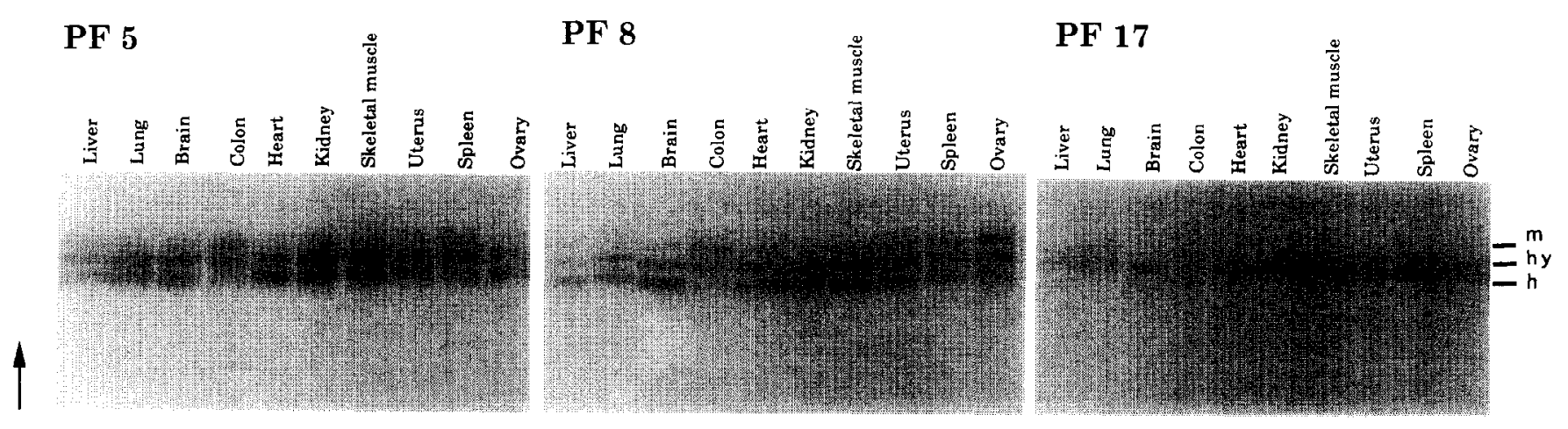

Fig. 3. Cellogel analysis of G6PD activity in a range of tissues from three lines of TG mice carrying the human G6PD gene. Lysates were prepared from tissues of mice from each of three TG lines carrying the human G6PD gene. The lysates were analysed on cellogels and stained for G6PD activity; the arrows show the direction in which the gels were run. Methods: Frozen tissues were homogenized in $2-3$ vols of G6PD lysis buffer in a Dounce homogenizer on ice, the homogenate was centrifuged at $13000 \mathrm{rpm}$ for $20 \mathrm{~min}$ at $4^{\circ} \mathrm{C}$, and clear supernatants were transferred to new tubes and kept on ice. The methods used for cellogel analysis are described in the legend to Fig. 2.

\section{PF 8}
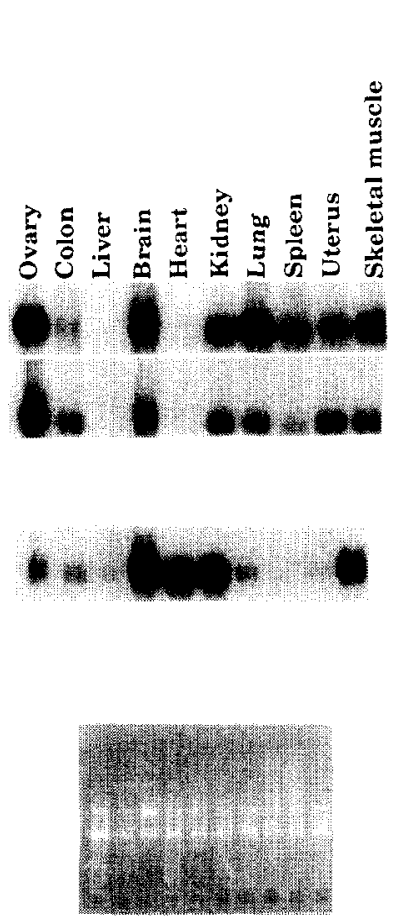

PF 17
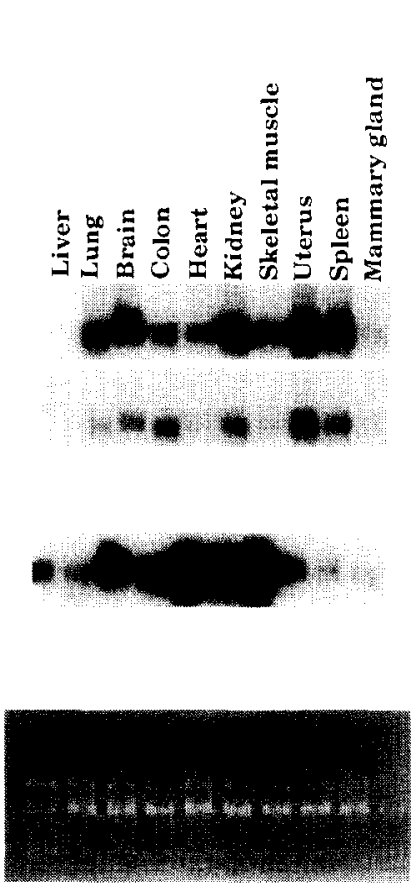

\section{PF 5}
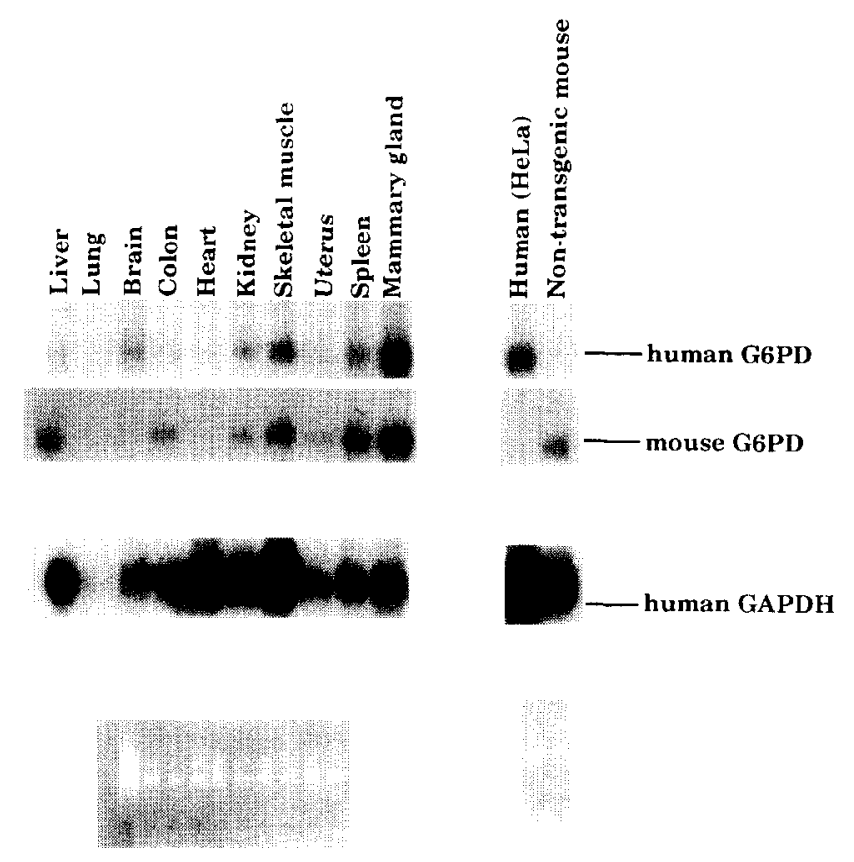

Fig. 4. G6PD mRNA expression in a range of tissues from three lines of TG mice carrying the human G6PD gene. Total RNA was prepared from the frozen tissues of mice representing the TG lines PF8, PF17 and PF5. $10 \mu \mathrm{g}$ of each sample were fractionated by electrophoresis in $1.25 \%$ agarose, blotted to nylon filters and hybridized at $42^{\circ} \mathrm{C}$ with radioactively-labelled probes to detect mRNA for mouse and human $G 6 P D(2.2 \mathrm{~kb})$ and for GAPDH $(1.3 \mathrm{~kb})$. The filters were washed in $2 \times \operatorname{SSC}(G A P D H)$ or $0.2 \times \mathrm{SSC}(G 6 P D)$ at $42^{\circ} \mathrm{C}$ and exposed to Kodak XAR 5 film. $0.25 \mu \mathrm{g}$ of each sample were visualized on ethidium bromide-stained mini-gels ( $1 \%$ agarose) to evaluate the amount and integrity of the material from the $28 \mathrm{~S}(-5000 \mathrm{nt})$ and $18 \mathrm{~S}$ (approx. $1900 \mathrm{nt}$ ) rRNA bands, and samples from NTG littermates and from HeLa cells were included in the analysis to demonstrate the species specificity of the probes. For the PF8 Northern shown the human G6PD probe was labelled to a specific activity of $5.9 \times 10^{8} \mathrm{cpm} / \mu \mathrm{g}$ and exposure time was $24 \mathrm{~h}$; the mouse G6PD probe was labelled to a specific activity of $6.3 \times 10^{8} \mathrm{cpm} / \mu \mathrm{g}$ and exposure time was $96 \mathrm{~h}$; GAPDH probe, $2.8 \times 10^{8} \mathrm{cpm} / \mu \mathrm{g}, 24 \mathrm{~h}$. For the PF17 Northern the figures were; human probe, $0.8 \times 10^{8} \mathrm{cpm}, 120 \mathrm{~h}$; mouse probe, $0.5 \times 10^{8} \mathrm{cpm} / \mu \mathrm{g}, 144 \mathrm{~h} ; \mathrm{GAPDH}$ probe, $14 \times 10^{8} \mathrm{cpm} / \mu \mathrm{g}, 6 \mathrm{~h}$. For the PFS Northern; human probe, $4.5 \times 10^{8} \mathrm{cpm} / \mu \mathrm{g}, 24 \mathrm{~h}$; mouse probe, $1.3 \times 10^{8} \mathrm{cpm} / \mu \mathrm{g}, 144 \mathrm{~h} ; \mathrm{GAPDH}$ probe, $14 \times 10^{8}$ cpm/ $/ \mu \mathrm{g}, 6 \mathrm{~h}$. Methods: RNA extraction was carried out by the method of Chirgwin et al. (1979). Northern blotting was carried out as described previously (Mason et al., 1993). Probes used for Northern blotting were: human G6PD, a 270-bp genomic XhoI fragment from the $3^{\prime}$ non-coding region; murine G6PD, a 160-bp XbaI-EcoRI fragment from a cloned portion of the $3^{\prime}$ non-coding region of the mouse G6PD gene; human GAPDH, a 777-bp genomic BamHI fragment. 
Representative Northern blots (Fig. 4) show that the variation in mouse G6PD mRNA levels between tissues is similar to the variation in G6PD activity with uterus and ovary having the highest levels and heart and liver the lowest. In each mouse, the TG was expressed in all of the tissues examined and the pattern of expression of the TG mRNA from tissue to tissue was almost indistinguishable from the pattern of expression of the endogenous murine G6PD mRNA; the ratio of human G6PD mRNA to murine G6PD mRNA was similar in the different tissues. There was one exception - the ratio of human to murine G6PD mRNA was lower in the colon than in any of the other tissues, and this difference was consistent in each of the mice analysed. The specificity of the human and murine probes was demonstrated by routinely including one track of NTG murine mRNA and one track of human mRNA on the filters. After autoradiography and phosphorimaging, the filters were stripped prior to re-hybridization with a probe for human GAPDH.

In all mice examined the steady-state mRNA level per gene copy was to a first approximation similar for the human TG and the endogenous mouse gene. For example in the experiment on line PF8 shown in Fig. 4 the human and mouse bands are of equal intensity. The exposure time with the human probe is a quarter of that with the mouse probe while the human probe is twice as long and there are two copies of the human gene. Since the specific activity of both probes is similar, the human and mouse mRNA levels per gene copy are approximately equal.

\section{(e) The tsp of the human gene in TG mice}

To verify that the mRNA levels and enzyme activities encoded by the human TG were due to activity of the human promoter, we determined the tsp of human G6PD mRNA from TG mouse tissues by $\mathrm{S} 1$ nuclease mapping. The result (Fig. 5) shows that the cap site of the human mRNA in mouse tissues is the same as in normal human fibroblasts.

\section{(f) Conclusions}

(1) Although the G6PD gene is located in a gene dense region of Xq28 along with scvcral other housekeeping genes all the cis-acting regulatory elements seem to be within the $20-\mathrm{kb}$ region containing the structural gene and its immediate flanking sequences. The construct was expressed in all of the founder mice and $\mathrm{TG}$ lines examined at levels which were at least as high as the endogenous gene - strong evidence that the TG expression was unaffected by its position of integration. The expression of the TG increased with a higher TG number - though the range of copy numbers was narrow. Tissue-specific

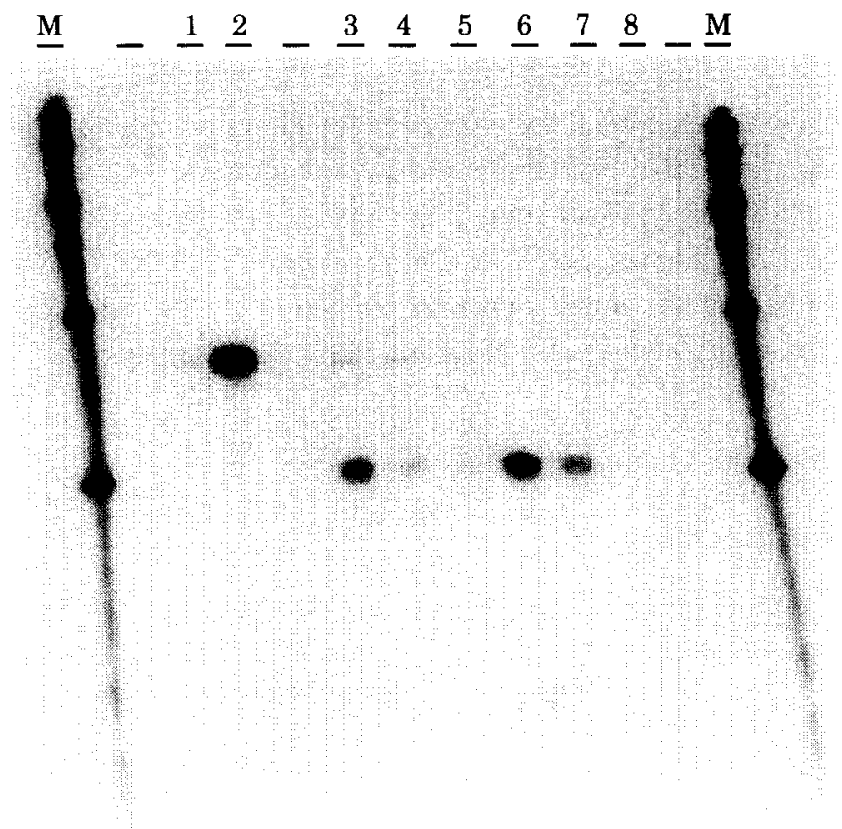

Fig. 5. Mapping the $t s p$ of the human G6PD TG in normal human fibroblasts and in TG kidney. Total RNA was isolated from the kidney of a mouse from the TG line PF 17 and from the human fibroblast cell line MRC 5. Samples were hybridized at $65^{\circ} \mathrm{C}$ to the radioactivelylahelled mapping prohe $\mathrm{pHB}$, digested with $\mathrm{S} 1$ nuclease at $13^{\circ} \mathrm{C}$ for 60 min, and analyzed on a $6 \%$ polyacrylamide gel. Lanes: control - no RNA included (1), control - no RNA included/no S1 nuclease treatment (2), 5.0, 2.5 and $0.5 \mu \mathrm{g}$ TG kidney RNA (3, 4 and 5); 5.0, 2.5 and $0.5 \mu \mathrm{g}$ human fibroblast RNA (6,7 and 8), TaqI + PvuII-digested pEMBL size markers (M; sizes in bp: 1008, 613, 357, 278, 193, 108). Methods: S1 mapping was carried out by standard procedures (Mason et al., 1993) using as probe a single-stranded 158-bp HaeII-BamHI DNA fragment $(\mathrm{pHB})$ spanning the normal $t s p$ in the human G6PD gene. The probe was prepared from $\mathrm{p} 5 \mathrm{~B}$, a cDNA clone which extends into the promoter region beyond the most commonly used cap site (Martini et al., 1986).

variation in expression was similar for the TG and the endogenous mouse G6PD.

(2) For the G6PD activity of both mouse and human, it was found that the variations in enzyme activity measured from one tissue to another were mirrored by variations in the steady-state mRNA levels. This suggests that tissue-specific regulation of the G6PD gene occurs at either the rate of synthesis or degradation of mRNA, and not at the translational or post-translational levels.

(3) In the colon, the expression differed from the other tissues in that there was consistently a relative deficiency of human G6PD mRNA and enzyme. Either this could be because of a real species-specific difference in colon specific G6PD expression or some colon-specific regulatory element has not been included in the introduced construct. The high levels of expression in all other tissues examined, and their similarity to the endogenous expression levels would tend to favour the first possibility. 


\section{ACKNOWI.FDGEMENTS}

We thank Frank Grosveld for his generous collaboration, and the following people for materials: Franco Calabi ( $\beta$-actin-encoding $(A c t)$ probe), Francis Benham (GAPDH probe), and Pier Paolo Pandolfi (mouse G6PD probe). This work was supported by the Medical Research Council and the European Community.

\section{REFERENCES}

Bione, S., Tamanini, F., Maestrini, E., Tribioli, C., Poustka, A., Torri, G., Rivella, S. and Toniolo, D.: Transcriptional organization of a 450-kb region of the human X chromosome in Xq28. Proc. Natl. Acad. Sci. 90 (1993) 10977-10981.

Calabro, V., Mason, P.J., Civitelli, D., Cittadella, R., Filosa, S., Tagarelli, A., Martini, G., Brancati, C. and Luzzatto, L.: Genetic heterogeneity of glucose-6-phosphate dehydrogenase deficiency revealed by single strand conformation analysis. Am. J. Hum. Genet. 52 (1993) $527-536$

Chirgwin, J.M., Przybyla, A.E., MacDonald, R.J. and Rutter, W.J.: Isolation of biologically active ribonucleic acid from sources enriched in ribonuclease. Biochemistry 18 (1979) 5294-5299.

Dillon, N. and Grosveld, F.: Transcriptional regulation of multigene loci - multilevel control. Trends Genet. 9 (1993) 134-137.

Kletzien, R.F., Harris, P.K.W. and Foellmi, L.A.: Glucose-6-phosphate dehydrogenase: a 'housekeeping' enzyme subject to tissue-specific regulation by hormones, nutrients, and oxidant stress. FASEB J. 8 (1994) 174-181.

Martini, G., Toniolo, D., Vulliamy, T.J., Luzzatto, L., Dono, R., Viglietto, G., Paonessa, G., D'Urso, M. and Persico, M.G. Structural analysis of the X-linked gene encoding human glucose6-phosphate dchydrogenase. EMBO J. 5 (1986) 1849-1855.

Mason, P.J., Enver, T., Wilkinson, D. and Williams, J.: Assay of gene transcription in vitro. In: Hames, B.D. and Higgins, S.J. (Eds.), Gene Transcription: A Practical Approach. IRL Press, Oxford, 1993, pp. 5-63.

Philippe, M., Larondelle, Y., Lemaigre, F., Mariame, B., Delhez, H., Mason, P., Luzzatto, L. and Rousseau, G.G.: Promoter function of the human glucose-6-phosphate dehydrogenase gene depends on two GC boxes that are cell specifically controlled. Eur. J. Biochem. 226 (1994) 377-384.

Rattazzi, M., Bernini, L., Fiorelli, G. and Mannucci, P.: Electrophoresis of G6PD: a new technique. Nature 213 (1967) 79-80.

Ruwende, C., Khoo, S.C., Snow, R.W., Yates, S.N.R., Kwiatkowski, D., Gupta, S., Warn, P., Allsop, C.E.M., Gilbert, S.C., Peschu, N., Newbold, C.I., Greenwood, B.M., Marsh, K. and Hill, A.V.S.: Natural selection of hemi- and heterozygotes for G6PD deficiency in Africa by resistance to severe malaria. Nature 376 (1995) 246-249.

Ursini, M., Scalera, L. and Martini, G.: High tevels of transcription driven by a $500 \mathrm{bp}$ segment of the human G6PD promoter. Biochem. Biophys. Res. Commun. 170 (1990) 1203-1209.

Vulliamy, T., Mason, P. and Luzzatto, L.: The molecular basis of glucose-6-phosphate dehydrogenase deficiency. Trends Genet. 8 (1992) 138-143.

Wang, Y., Macke, J.P., Merbs, S.L., Zack, D.J., Klaunberg, B., Bennett, J., Gearhart, J. and Nathans, J.: A locus control region adjacent to the human red and green visual pigment genes. Neuron 9 (1992) $429-440$. 